\title{
DETERMINANTS OF AGRIPRENEURIAL CAREER INTENTIONS: EVIDENCE FROM AGRICULTURE STUDENTS
}

\author{
Suprehatin ${ }^{* * *) 1}$ and Muhammad Rasyid Shidiq ${ }^{* *}$ \\ *) Department of Agribusiness, Faculty of Economics and Management, IPB University \\ Jl. Kamper Wing 4 Level 5 Kampus IPB, Dramaga Bogor 16680 , Indonesia \\ ${ }^{* *}$ Center for Agriculture and Rural Development Studies, IPB University \\ Jl. Raya Pajajaran, Bogor 16129, Indonesia
}

\begin{abstract}
The participation of young people in agriculture is essential for addressing issues of food security, youth unemployment, ageing farmers, and the digital revolution in the agriculture and food sectors. Various programs have been conducted by the Government of Indonesia (including One Million Millennial Farmers Movement Program), by the private sector, and by universities to raise the interest of students and increase the number of young farmers in the agricultural and food industry. These programs are a response to the continuing decline in the number of Indonesian farm households and the need to attract younger entrants into the industry. This study analyses the factors that influence the intention of agricultural students to become agripreneurs using a modified theory of planned behaviour (TPB) approach. Data obtained from a survey of 204 agricultural students at IPB University using a voluntary sampling method and analysed using partial least squares structural equation modelling (PLS SEM). The results showed that individual characteristics, attitudes, subjective norms, and perceived behavioural control of agricultural students had a significant effect on the intention to become an agripreneur. The study also showed that family background did not significantly influence the intention of agricultural university students to become an agripreneur. The findings contribute to the literature by providing a better understanding of the role that agriculture education and training plays in increasing students' intention to work in agriculture.
\end{abstract}

Keywords: agriculture education, agripreneur, agripreneurship, intention, youth farmer

Abstrak: Partisipasi generasi muda di sektor pertanian sangat penting karena terkait dengan isu strategis seperti ketahanan pangan, pengangguran, regenerasi petani, dan revolusi digital di sektor pangan dan pertanian. Berbagai program telah dilakukan oleh pemerintah (seperti Gerakan Sejuta Petani Milenial), pihak swasta dan universitas untuk meningkatkan minat mahasiswa dan jumlah petani muda di sektor pertanian. Program tersebut untuk merespon jumlah rumah tangga petani Indonesia yang terus menurun dan kebutuhan untuk menarik generasi muda bekerja di pertanian. Penelitian ini bertujuan untuk menganalisis faktor yang memengaruhi intensi mahasiswa pertanian menjadi wirausaha pertanian dengan menggunakan pendekatan modifikasi TPB. Data diperoleh dari survei terhadap 204 mahasiswa pertanian di IPB University menggunakan teknik voluntary sampling dan dianalisis menggunakan PLS SEM. Hasil penelitian menunjukan bahwa karakteristik individu, sikap, norma subjektif, dan kontrol perilaku dari mahasiswa pertanian berpengaruh secara signifikan terhadap intensi mahasiwa menjadi wirausaha pertanian. Hasil penelitian juga menunjukan bahwa faktor keluarga tidak berpengaruh secara signifikan terhadap intensi mahasiswa pertanian menjadi wirausaha pertanian. Penelitian ini berkontribusi pada literatur dengan memberikan pemahaman yang lebih baik bahwa pendidikan dan pelatihan di bidang pertanian berperan penting dalam meningkatkan niat mahasiswa untuk bekerja di sektor pertanian.

Kata kunci: agripreneur, intensi, kewirausahaan pertanian, pendidikan pertanian, pemuda tani

\footnotetext{
${ }^{1}$ Corresponding author:

Email: suprehatin@apps.ipb.ac.id
} 


\section{INTRODUCTION}

Agriculture is vital in many developing countries where it is the main occupation of the poor. It is a significant driver of development providing economic growth, poverty reduction, reduced sectoral disparities, food security, and providing environmental services (Byerlee et al. 2009). On the other hand, the participation of young people in agriculture is essential in addressing issues of youth unemployment, ageing farmers, and the digital revolution in the agriculture and food sectors. However, the participation of youth in agricultural production remains low.

In Indonesia, various programs have been established by the government to raise the number of young farmers, including One Million Millennial Farmer Movement Program from the Ministry of Agriculture recently in 2019. Government support is not surprising because over the 10 years from 2003-2013, the number of Indonesian farmer's households decreased up to 5 million people. The data from Agriculture Census 2013 also predicts that this number will keep declining at a rate of $1.75 \%$, or more than 500 thousand people per year. One of the main reasons for the decline is a lack of interest of young people to work in the agriculture sector. Farmer age structure data shows that the majority of farmers are aged more than 50 years $(47.57 \%)$. In contrast, the youth from ages 15-29 are less than 5\% of the total farmer population (BPS, 2013).

One way to attract youth to agriculture is to adopt an entrepreneurial approach to the developmentof the sector (Sopyan, 2013). Agripreneurship (Entrepreneurship in Agriculture) could solve financial issues by generating income higher than the non-agriculture sectors as a means to attract the young generation (Nugroho et al. 2018). Agripreneurship also presents other opportunities for entrepreneurial development as a breeding ground for micro and small enterprises (Barau \& Adesiji, 2017). To support agripreneurship, the Indonesian government through the Food Security Agency in Ministry of Agriculture has conducted programs such as the agricultural high school reformation, a young agriculture entrepreneurship program (e.g. penumbuhan wirausahawan muda pertanian-PMWP), joint business groups for young farmers and other agriculture trainings and seminars.
Universities and agriculture institutes are also part of government strategies to stimulate young farmers regeneration. Students are expected to contribute in the agriculture sector after they have graduated, but many choose another field for their career. It is interesting to examine what are factors that influence the agriculture students' intention to work in agriculture, particularly as a farmer. However, instead of using term "farmer", we used "agricultural entrepreneur" or "agripreneur" to avoid misunderstanding or negative perception of the students toward farming activities. In this study, we consider agripreneurs to be people who work in any agriculture activities associated with farming activities or agricultural production. In other words, the study focuses on the agricultural activities related to the onfarm sub-system in the agribusiness system.

Previous studies have addressed these issues. Nugraha \& Herawati (2015) investigated what factors that drive young men and women in 12 rice production villages to leave or stay to work in agriculture sectors. They concluded that the youth in these villages were not so attracted to work in agriculture sector, because they only intend to make agriculture as secondary option when they have no better job. Wiyono (2015) also study factors that affect the farmer's family member in rice production centre area to become a farmer. Hamyana (2017) conduct a study about young farmers group motives to work in agriculture sector in Batu villages. These studies are targeted at young people in the rural areas. The study reported here contributes to the existing research by examining the youth intention both from urban and rural areas with exposure of agriculture. In particular, the study aims to analyse the determinants of agripreneurial career intention among university agriculture students.

Furthermore, the study considers additional factors such as gender, level of education and previous experience that can impact on career intentions. Wiyono (2015) investigated the role of gender in agriculture sector. The results showed that agriculture is dominated by male rather than female. Keat et al. (2011) also found that there is linkage between gender and entrepreneurial intention. Meanwhile Panurat (2014) revealed that farming experience is significantly correlated with the intention of farmer to continue their job. The type of place of origin whether it is an agicultural centre area or not, is also affect the intention to be involved in agriculture (Nugraha \& Herawati 2015; Wiyono, 2015) 
that conducted their research in agicultural centre area. Agricultural education, both formal or informal also affects someone's intention to work in the agriculture sector according to Fayolle and Gailly (2015). They stated that the student's intention to be an entrepreneur can be influenced by entrepreneurship courses in which students can enroll.

On the other hand, this study also considered familial factors such as parent's education level, parent's job, and ownership of farm as potential factors affecting intention to be an agripreneur. Current research found that the young generation tends to continue their parent's business, including in agricultural business (Nugroho et al. 2018). Arimbawa and Rustariyuni (2018) also stated that the high level education could increase the rationality level of society. The higher the level of education of someone, the lower the intention of them to choose agriculture as their workfield. In addition, Gasson (2008) highlighted that there is a greater tendency for a young person to work in agriculture sector come from a family owning larger areas of land, rather than those from small holdings or from farms where the land is rented.

This study incorporates personal and familial factors into the structural model of theory of planned behaviour (TPB) by Ajzen (1991). The TPB approach is commonly used in research related to entrepreneurial intention (e.g. Krueger et al. 2000; Harris et al. 2007; Yang, 2013; Liñán et al. 2013; Fayolle \& Gailly 2015; Nguyen, 2017). It consists of three leading $\neg$ independent variables that affect intentions, namely attitude, subjective norm, and perceived behavioural control. This study investigates the determinant factors affecting student's intention to be agripreneur.

\section{METHODS}

The study used data obtained from a survey of 204 agricultural students at IPB University from various study programs using a voluntary sampling method. An online survey is used to collect data from these voluntary contributors. Alink of survey was distributed via authors' social media such as WhatsApp Group, Facebook, Instagram, and Line. The data collection occurred from May to June 2019. Then we performed a data analysis by partial least squares (PLS) as a component-based structural equation modelling approach and based on the TPB framework (Figure 1). To carry out the data analyses, we used SmartPLS (version 3.0, SmartPLS $\mathrm{GmbH}$, Boenningstedt, Germany) (Ringle et al. 2015).

\section{Theory of Planned Behaviour}

The main framework used in this research is the theory of planned behaviour (TPB) with a modification on the independent variables. The TPB developed by Ajzen (1991) is commonly used as framework model in entrepreneurial intention research (Liñán \& Chen, 2009). In this model, three fundamental independent variables are affecting intention, namely attitude, subjective norms, and perceived behavioural control. Attitude is a subjective judgment of the consequences of people's specific behaviour and its influence on people, which determines whether people like or dislike that kind of behaviour. While subjective norms refer to individual's perceptions based on the perception of people they think are important to them, to perform or not perform a certain behaviour. Perceived behavioural control refers to the subjective understanding of the level of people's self-control and the difficulty of conducting certain behaviour (Ajzen, 1991). According to Ajzen (1991), the three different equations were used to obtain individual TPB's variables as follows:

i. $A=\sum_{\mathrm{i}=1}^{\mathrm{n}} \mathrm{b}_{\mathrm{i}} \mathrm{e}_{\mathrm{i}}$

ii. $\mathrm{SN}=\sum_{\mathrm{i}=1}^{\mathrm{n}} \mathrm{n}_{\mathrm{i}} \mathrm{m}_{\mathrm{i}}$ iii. $\mathrm{PBC}=\sum_{\mathrm{i}=1}^{\mathrm{n}} \mathrm{c}_{\mathrm{i}} \mathrm{p}_{\mathrm{i}}$

where A is attitude toward behaviour, bi is belief strength, ei is evaluation of outcome, $\mathrm{SN}$ is subjective norm, ni is normative bbeliefs, $\mathrm{mi}$ is motivation to comply, PBC is perceived behavioural control, ci is belief of control and pi is power of perceived.

Next, these three individual scores, namely attitude (A), subjective norm ( $\mathrm{SN}$ ) and perceived behavioral control (PBC) were transformed to 0 to 100 scale respectively. This standardized scale make individual TPB's components easier to be interpreted. The scale was divided into three categories, namely high, intermediate, and low, using equation as follows (Slamet, 1993):

Class Interval $(\mathrm{I})=\underline{\text { Highest Score }(\mathrm{HS})-\text { Lowest Score }(\mathrm{LS})}$ Total Sample 
Where low is LS until (LS+I), intermediate is (LS+I) until (LS+2I) and high is (LS+2I) until HS.

In order to widen the scope of causal factors, two main independent determinants were added besides those three original variables from Ajzen, namely personal and familial factors. The modified of the conceptual framework of this study can be seen at Figure 1. The addition of personal and familial factors were based on findings on prior research such as Wiyono (2015), Panurat (2014), Nugraha and Herawati (2015) who found that gender, type of student origin (whether they come from agricultural centre area or not), the farming experiences, and agricultural education play important roles to the intention to work in agriculture sector. There are also other studies such as Nugroho et al. (2018), Meliasari (2017) and Gasson (2008) who found that essential factors like parent's job, parent's education, and the ownership of agricultural land affected the youth's consideration to work in agriculture sector.

Based on the theoretical concept and previous studies, the hypothesis of this study as follows:

H1 : Attitude affects positively and significantly the agripreneurship intention of students.

$\mathrm{H} 2$ : Subjective norms have a positive and significant effect on student agripreneurship intention.

H3 : Perceived behavioural control influences positively andsignificantly theagripreneurship intention of students.
H4 : Individual characteristics have a positive and significant impact on student agripreneurship intention.

H5 : Familial characteristics influence positively and significantly to student agripreneurship intention.

Partial Least Squares Structural Equation Modelling (PLS SEM)

This study used partial least squares structural equation modelling(PLS SEM) todiscover the relationshipamong the variables, either the relationship between indicators and correlating variables or between independent and dependent variables. Three different tests also have been done to examine the eligibility of the model which are convergent validity, discriminant validity, and composite reliability. First, convergent validity is used to measure the validity of the question or indicators to their correlating variables. Vinzi et al. (2010) stated that the minimum loading factor value required is 0.6 , otherwise the indicators must be removed for further calculation because it has no sufficient influence. It turned out that there are some invalid indicators according to those criteria, including gender and type of student origin in individual characteristics, and education of father in family characteristics. Therefore, those indicators were removed for SEM calculation.

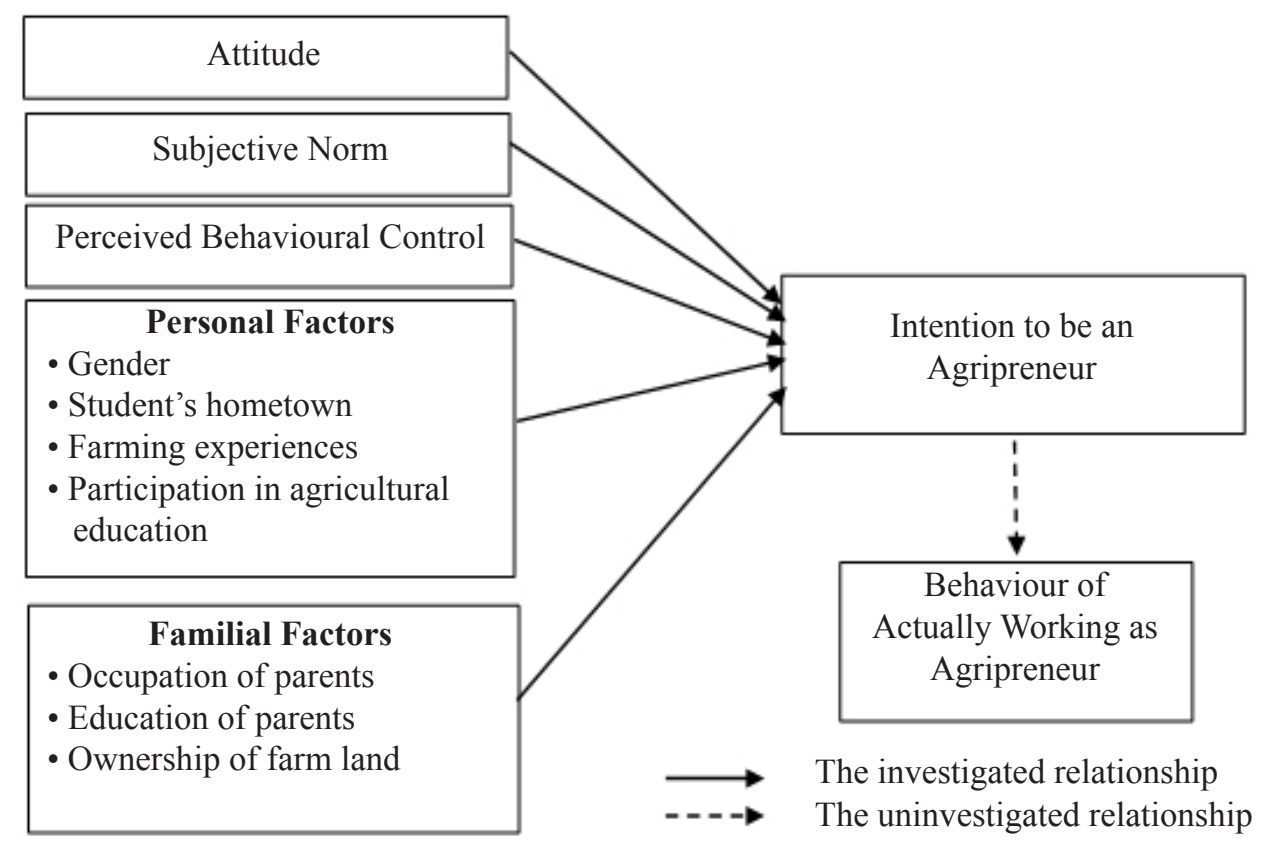

Figure 1. Research framework 
Second, discriminant validity is the standard to measure the validity of the variables involved in the model based on a comparison between the value of square root of average variance extracted (AVE) of each variable. The results showed that all of the variables used in this model are valid for further SEM calculation. Another test, composite reliability, is used to determine the reliability of each variable. According to Hair et al. (2014), the minimum value of each variable must be 0.6 , otherwise the variable is not reliable and must be eliminated. The results confirmed that all of variables used in this model are reliable and can be included in further SEM modelling.

\section{RESULT}

\section{Individual and Familial Characteristics of Respondents}

Individual and familial characteristics important factors influencing youth engagement in the agriculture and food sector. Table 1 shows that most of the respondents come from non-agriculture centre area $(69.1 \%)$, or urban area which has dense population. $72.1 \%$ of respondents have never been involved in any farming activities previously and majority of the student's parent work is not as an agripreneur or other farming-related jobs. Table 1 also shows that most of student's parents have relatively high educational background, approximately $75 \%$ of them were senior high school graduate, and capable of getting proper job in the city area.

Participation of students in formal agricultural courses (the number of subjects or lecturers they have attended during their study in IPB university) is recorded in the Table 1. Participation varies and depends on what major students took in the university. Students from agricultural-related majors such as agronomy and horticulture, agribusiness and soil science had have more agricultural formal courses than non agriculturalrelated majors like computer science, management, and economics (Table 1).

Table 1. Individual and familial characteristics of respondents $(n=204)$

\begin{tabular}{|c|c|c|c|c|c|}
\hline \multirow{2}{*}{ Characteristics } & \multicolumn{5}{|c|}{ Category } \\
\hline & \multicolumn{5}{|c|}{ Frequency (Percentage) } \\
\hline \multicolumn{6}{|l|}{ Individual Characteristics } \\
\hline \multirow[t]{2}{*}{ Gender } & Male & Female & & & \\
\hline & $80(39.2 \%)$ & $124(60.8 \%)$ & & & \\
\hline \multirow[t]{2}{*}{ Hometown } & Rural area & Urban area & & & \\
\hline & $63(30.9 \%)$ & $141(69.1 \%)$ & & & \\
\hline \multirow[t]{2}{*}{ Farming experiences } & Yes & No & & & \\
\hline & $57(27.9 \%)$ & $147(72.1 \%)$ & & & \\
\hline \multirow[t]{2}{*}{ Participated in formal agriculture course } & $1-5$ times & 6-10 times & 11-15 times & 16-20 times & $>20$ times \\
\hline & $150(73.5 \%)$ & $28(13.7 \%)$ & $10(4.9 \%)$ & $9(4.4 \%)$ & $7(3.5 \%)$ \\
\hline \multirow[t]{2}{*}{ Participated in informal agriculture course } & 0 time & $1-3$ times & 4-6 times & 7-9 times & 10-12 times \\
\hline & $58(28.5 \%)$ & $102(50 \%)$ & $33(16.1 \%)$ & $4(2 \%)$ & $7(3.4 \%)$ \\
\hline \multicolumn{6}{|l|}{ Familial Characteristics } \\
\hline \multirow[t]{2}{*}{ Occupation of father } & On/off-farm & Non-farm & & & \\
\hline & $22(10.8 \%)$ & $182(89.2 \%)$ & & & \\
\hline \multirow[t]{2}{*}{ Occupation of mother } & On/off-farm & Non-farm & & & \\
\hline & $10(4.9 \%)$ & $194(94.1 \%)$ & & & \\
\hline \multirow[t]{2}{*}{ Education of father } & ES & JHS & SHS & Bachelor & $>$ Bachelor \\
\hline & $23(11.3 \%)$ & $16(7.8 \%)$ & $69(33.8 \%)$ & $80(39.2 \%)$ & $16(7.8 \%)$ \\
\hline \multirow[t]{2}{*}{ Education of mother } & ES & JHS & SHS & Bachelor & $>$ Bachelor \\
\hline & $27(13.2 \%)$ & $20(9.8 \%)$ & $76(37.3 \%)$ & $69(33.8 \%)$ & $12(5.9 \%)$ \\
\hline \multirow[t]{2}{*}{ Owned-farmed land } & $0 \mathrm{Ha}$ & $<0.5 \mathrm{Ha}$ & $0.5-1 \mathrm{Ha}$ & 1-2 Ha & $>2 \mathrm{Ha}$ \\
\hline & $117(57.4 \%)$ & $46(22.5 \%)$ & $21(10.3 \%)$ & $10(4.9 \%)$ & $10(4.9 \%)$ \\
\hline
\end{tabular}


In contrast, the participation of students in informal agricultural courses (including seminars, training and workshops) depends on the initiative of the students itself. Table 1 shows that the majority of students (50\%) have participated in one to three informal agricultural courses. Table 1 also reveals that there are more student's parents that did not own agricultural land $(57.4 \%)$. Where land is owned, the majority is less than 0.5 hectares.

\section{Attitude, SubjectiveNormand Perceived Behavioural Control toward Agripreneurial Careers}

This study measured the scores of the three TPB's components, which are attitude, subjective norm, and perceived behavioural control, among agriculture students based on their answers to the related questions. The sum of the scores is then classified into three categories, which are low, intermediate, and high, using the class interval method as explained above. Table 2 shows that $53.9 \%$ of agriculture students have a high level of attitude toward agripreneur career, and no single student has a low level of this attitude. These results indicate that agriculture students perceive agripreneurship as a job which brings excellent values and benefits. None of the students argue that agripreneurship is an occupation with poor prospects.

On the other hand, the majority of agriculture students has a low level (48.5\%) and moderate level (44.6\%) of subjective norm toward agripreneurial activities (Table 2). Most of the agriculture students think that the people who they consider as important roles (e.g. parents, friends, lecturers) have little influence on them to work as an agripreneur. These students are also not affected by people's opinion when it comes to the intention to work as an agripreneur.

In terms of perceived behavioural control, the students are dominated by intermediate level $(59.8 \%)$ of perceived behavioural control score and followed by a low level (30.9\%) (Table 2). This implies that they have moderate and low belief that they can be an agripreneur based on the information, experiences, and conditions they have already experienced. Few students $(9.8 \%)$ who has high level of this TPB component. Most of students also think that they have moderate and low control over the decision to become an agripreneur

\section{The Intention to be an Agripreneur}

This study uses three variables to study intention: (1) whether the students want to try to be an agripreneur during their study in the university; (2) whether they want to make agripreneur as their secondary job or just a hobby; and (3) whether they want to make agripreneur as their primary job.

The results reveal that the highest intention of the students is to make agripreneur as their secondary job, or merely a hobby in their spare time. The lowest intention is to try to be an agripreneur during their study in university. These results correlate with the previous results (see Table 2) regarding the level of perceived behavioural control of the students - about $80 \%$ of the students believe that they have moderate and low levels of behavioural control. However, it does not means that the intention to be an agripreneur amongst agriculture students is relatively low. As seen in Table 2 , it is evident that agriculture students tend to have a good perception about agripreneur and its benefit. Therefore, it can be concluded that the students are likely to make agripreneur although as their secondary job or profitable hobby.

\section{The Determinant Factors towards the Intention to Work as an Agripreneur}

The study used the PLS SEM model to examine the determinant factors affecting agriculture students' intention to be an agripreneur. From the five independent variables studied, there are four that have significant influence on intention, namely personal characteristics, attitude, subjective norm, and perceived behavioural control (Table 3). The results support hypotheses 1, 2, 3 and 4 as explained above. Perceived behavioural control becomes the highest predictor for intention, followed by attitude, personal factors, and subjective norm. This results support a previous study that found perceived behavioural control as the highest predictor for entrepreneurial intention, followed by attitude and subjective norm (Krueger et al. 2000).

Table 3 shows that all significant TPB's variables have a positive coefficient, which means that the higher attitude $(\beta=0.175, P<0.05)$, subjective norm $(\beta=0.158$, $\mathrm{P}<0.05)$, and perceived behavioural control $(\beta=0.373$, $\mathrm{P}<0.01)$ a student has, the higher their intention to be 
an agripreneur. These results are similar to the previous research done by Yang (2013) who investigated the intention to be entrepreneur of Chinese students using TPB approach. The research found that attitude, subjective norm and perceived behavioural control have significant role in affecting the student's intention to be entrepreneur.

For individual factors $(\beta=0.165, \mathrm{P}<0.01)$, the more student has desired the characteristics, the higher their intention to be an agripreneur. Since gender and type of student's origin area are removed from the SEM modelling due to validity issue, the desired characteristics in individual factors refer to the participation of students in formal and informal agricultural courses and farming experience.

Students are likely to have a higher intention to work as an agripreneur if they have higher levels of exposure and participation in agricultural education, both formal and informal. This result is supported by the research of Fayolle and Gailly (2015) and Harris et al. (2007) who found that entrepreneurial intention can be affected by entrepreneurial education. Thus, it can be inferred that the students whose major is directly related to agriculture will have higher intention to be an agripreneur than the students in other majors or faculties. Similarly the students who have experience in farming, or involved directly in farming activities are more likely to have higher intention to be an agripreneur than the students that do not have experience.

Familial factors have no significant influence on the intention to be agripreneur amongst university students. Even the indicators like parent's job, the ownership of agricultural land, and area of agricultural land do not pass the minimum criteria for indicator validity test. This finding contradicted to the previous presumption that there is a strong relation between familial background and the agripreneurial intention. However, this is consistent with the research of Nguyen (2018) stated that there is no strong evidence of the relationship between familial factors and the intention to be an entrepreneur amongst business students. Similarly, Nguyen (2018) showed that personal characteristics had a significant effect on the business student's intention to be an entrepreneur.

\section{Managerial Implications}

The participation of young people in agriculture, including agriculturestudents, isnotonlyneeded towards addressing food security and youth unemployment challenges but also critical in addressing issues of ageing farmers and a digital revolution in the agriculture and food sectors. Furthermore, young people are essential resources required for every country to ensure their sustainable agricultural production.

Table 2. Scores of attitude, subjective norm and perceived behavioral control toward agripreneurial careers

\begin{tabular}{lccc}
\hline \multirow{2}{*}{ TPB Component } & \multicolumn{3}{c}{ Score $(\mathrm{n}=204)$} \\
\cline { 2 - 4 } & Low (4-36) & Intermediate (37-68) & High (69-100) \\
\hline Attitude & $0(0 \%)$ & $94(46.1 \%)$ & $110(53.9 \%)$ \\
Subjective Norm & $99(48.5 \%)$ & $91(44.6 \%)$ & $14(6.9 \%)$ \\
Perceived Behavioural Control & $62(30.4 \%)$ & $122(59.8 \%)$ & $20(9.8 \%)$ \\
\hline
\end{tabular}

Table 3. The effects of TPB components, personal and family factors toward intention to work as agripreneur

\begin{tabular}{lcc}
\hline Variables & Coefficients & P-Values \\
\hline Attitude $\rightarrow$ Intention & $0.175^{* *}$ & 0.017 \\
Subjective Norm $\rightarrow$ Intention & $0.158^{* *}$ & 0.043 \\
Perceived Behavioural Control $\rightarrow$ Intention & $0.373^{* * *}$ & 0.000 \\
Personal Characteristics $\rightarrow$ Intention & $0.165^{* * *}$ & 0.007 \\
Familial Characteristics $\rightarrow$ Intention & -0.029 & 0.577 \\
\hline
\end{tabular}

Notes: $* * *, * *, *$ indicate statistical significance at the $1 \%, 5 \%$ and $10 \%$ levels, respectively. 
As discussed above, the findings of this study will undoubtedly have implications which may be useful as for policymakers in terms of increasing the young farmers or agripreneur in Indonesia. Since all of TPB components, namely attitudes, subjective norms, and perceived behavioural controls, have significant effect on intention, policymakers can address these variables to improve youth intention to engage in the agriculture and food sectors. It can be achieved, for example, by creating awareness of the value of being an agripreneur through advertisement or promotion in social media. Teachers in junior high school and senior high school also can be asked to promote the potential of agriculture sector to the students. This could focus on raising awareness of modern agriculture and addressing old perceptions that agriculture is dirty and merely a job for poor people in villages.

The way to increase the subjective norm level is quite similar to the way to increase the attitude level. The people whom students think important such as parent, teacher, friend, influencer, or public figure, could create a collective perspective and norm that being agripreneur brings good value and benefit. Also, to elevate the perceived behavioural control level, the policy maker or government can provide incentives for agripreneurship, including the access to capital, knowledge, and assurance of being successful in agriculture sector. The students might think that agriculture is too risky and hard to do, because they do not have right understanding and information access.

Besides the TPB components, personal determinants such as farming experience, formal and informal agricultural education are proven to play important roles in a student's intention to be agripreneur. Therefore, the student's intention can be stimulated by giving greater exposure to agricultural education, both formal and informal. This can extend to providing opportunities for students to gain direct experience of farming. In terms of crop adoption, Suprehatin (2019) found that horticultural crop adopting farmers were significantly younger. This findings indicates that it is important to consider whether there is a need for specific horticultural production training program for university students in order to improve their skills. There is growing evidence that horticulture crops such as fruits and vegetables may more profitable and may offer more lucrative market opportunities than traditional, staple food crops (Roy \& Thorat, 2008; Schipmann \& Qaim, 2010). Benefitting from high-value horticultural farming activities is hoped can attract young people to be more engaged in agriculture as nascent agripreneur.

\section{CONCLUSIONS AND RECOMMENDATIONS}

\section{Conclusions}

This study identified different levels of attitude (high), subjective norm (low) and perceived behavioural control (moderate) amongst the 204 selected university agriculture students to be an agripreneur. Most of the agricultural students intend to be agripreneur as their secondary job or merely a profitable hobby, not as a primary profession. The findings of this study also revealed that attitude, subjective norm, perceived behavioural control and personal characteristics have positive significant influence towards student's intention to be agripreneur, while familial characteristics have not.

\section{Recommendations}

The findings recommend higher education to become a driving force in improving the agripreneurial student intention through agriculture education and training. On the other hand, in this study, only agricultural students in a particular university were considered. Therefore, future researchers could include both agricultural and non agricultural students elsewhere in the country considering their growing interest working in agricultural sector. A comparative study is also recommended to be carried out by future researchers. In addition, further research may also be conducted to analyse the relationship between the intention and the behavior to be nascent agripreneur amongst university students.

\section{ACKNOWLEDGEMENT}

The authors are thankful to Professor Shaun Coffey for proof-reading the paper. 


\section{REFERENCES}

Ajzen I. 1991. The theory of planned behavior. Organizational Behavior and Human Decision Processes 50(2): 179-211.

Arimbawa I, Rustariyuni S. 2018. Respon anak petani meneruskan usaha tani keluarga di kecamatan Abiansemal. E-Jurnal EP Unud 7(7): 15581586.

Barau AA, Adesiji GB. 2017. Socioeconomic determinants influencing the willingness of agriculture undergraduates to participate in agripreneurship in Northwest Nigeria. IJAMAD 8(1): 25-34.

[BPS] Badan Pusat Statistik. 2013. Laporan Hasil Sensus Pertanian 2013 (Pencacahan Lengkap). Jakarta: BPS.

Byerlee D, De Janvry A, Sadoulet E. 2009. Agriculture for development: Toward a new paradigm. Annual Review of Resource Economics 1: 1531.

FayolleA, GaillyB.2015. Theimpactofentrepreneurship education on entrepreneurial attitudes and intention: Hysteresis and persistence. Journal of Small Business Management 53(1): 75-93.

Gasson R. 2008. The choice of farming as an occupation. Sociologia Ruralis 9(2): 146-166.

Hair Jr JF, Hult GTM, Ringle C, Sarstedt, M. 2016. A Primer on Partial Least Squares Structural Equation Modeling (PLS-SEM). London: Sage Publications.

Hamyana. 2017. Motif kerja generasi muda di bidang pertanian: studi fenomenologi tentang motif kerja di bidang pertanian pada kelompok pemuda tani di kota Batu. MEDIAPSI 3(1): 34-42.

Harris ML, Gibson SG, Taylor SR. 2007. Examining the impact of small business institute participation on entrepreneurial attitudes. Journal of Small Business Strategy 18(2): 57-75.

Keat OY, Selvarajah C, Meyer D. 2011. Inclination towards entrepreneurship among university students: an empirical study of Malaysian university students. International Journal of Business and Social Science 2(4): 206-220.

Krueger NF, Reilly MD, Carsrud AL. 2000. Competing models of entrepreneurial intentions. Journal of Business Venturing 15(4): 411-432.

Liñán F, Chen YW. 2009. Development and crosscultural application of a specific instrument to measure entrepreneurial intentions. Entrepreneurship: Theory and Practice 33(3):
593-617.

Liñán F, Nabi G, Krueger N. 2013. British and Spanish entrepreneurial intentions: A comparative study. Revista de Economía Mundial 33: 73-103.

Meliasari. 2017. Hubungan kondisi sosial-ekonomi rumah tangga dengan minat pemuda desa di bidang pertanian (Desa Mulangsari, Kecamatan Pangkalan, Kabupaten Karawang). [thesis]. Bogor: Institut Pertanian Bogor.

Nguyen C. 2017. Entrepreneurial intention of international business students in Viet Nam: a survey of the country joining the TransPacific Partnership. Journal of Innovation and Entrepreneurship 6(7): 1-13.

Nguyen C. 2018. Demographic factors, family background and prior self-employment on entrepreneurial intention-Vietnamese business students are different: why?. Journal of Global Entrepreneurship Research 8(1): 1-17.

Nugraha YA, Herawati R. 2015. Menguak realitas orang muda sektor pertanian di pedesaan. Jurnal Analisis Sosial 19(1): 27-40.

Nugroho AD, Waluyati LR, Jamhari. 2018. Upaya memikat generasi muda bekerja pada sektor pertanian di Daerah Istimewa Yogyakarta. JPPUMA 6(1): 76-95.

Panurat SM. 2014. Faktor-faktor yang mempengaruhi minat petani berusaha tanipadi di Desa Sendangan Kecamatan Kakas Kabupaten Minahasa [thesis]. Manado: Universitas Sam Ratulangi.

Ringle CM, Wende S and Becker JM. 2015. SmartPLS 3. SmartPLS GmbH, Boenningstedt Germany. Available at: http://www.smartpls.com.

Roy D, Thorat A. 2008. Success in high value horticultural export markets for the small farmers: The case of Mahagrapes in India. World Development 36(10): 1874-1890.

Slamet. 1993. Analisis Kuantitatif untuk Data Sosial (cetakan ke-1). Semarang: Dabara Publisher.

Schipmann C, Qaim M. 2010. Spillovers from modern supply chains to traditional markets: product innovation and adoption by smallholders. Agricultural Economics 41(3/4): 361-371.

Sopyan RR. 2013. Pelatihan kewirausahaan sebagai upaya meningkatkan sikap kewirausahaan agribisnis bagi petani muda [thesis]. Bandung: Universitas Pendidikan Indonesia.

Suprehatin S. 2019. Characteristics of farmer adopters of high value horticultural crops in Indonesia. Jurnal Manajemen \& Agribisnis 16(2): 181190. 
Vinzi VE, Trinchera L, Amato S. 2010. Handbook of Partial Least Squares. Vinzi VE, Chin WW, Hanseler J, editor. Berlin: Springer.

Wiyono S. 2015. Kajian Regenerasi Petani. Bogor:

Koalisi Rakyat untuk Kedaulatan Pangan
(KRKP).

Yang J. 2013. The theory of planned behavior and prediction of entrepreneurial intention among Chinese undergraduates. Social Behavior and Personality 41(3): 367-376. 